\title{
Views of the Challenges and Opportunities of International Exchange and Cooperation Facing Universities and Colleges in the West under the Background of the Belt and Road Initiative
}

\author{
Luo Li \\ International Exchange and Cooperation Office, Sichuan University of Arts and Science, Dazhou, China \\ Email: jjswendy@163.com
}

How to cite this paper: Li, L. (2020). Views of the Challenges and Opportunities of International Exchange and Cooperation Facing Universities and Colleges in the West under the Background of the Belt and Road Initiative. Voice of the Publisher, 6, 40-46.

https://doi.org/10.4236/vp.2020.62005

Received: May 22, 2020

Accepted: June 26, 2020

Published: June 29, 2020

Copyright $\odot 2020$ by author(s) and Scientific Research Publishing Inc. This work is licensed under the Creative Commons Attribution International License (CC BY 4.0).

http://creativecommons.org/licenses/by/4.0/

\begin{abstract}
With the continuous improvement of China's international status and influence, General Secretary Xi Jinping proposed the "Belt and Road" economic development strategy, which provides a good opportunity for the development of many areas such as the economy, foreign trade, and talent exchange to countries along the route. To ensure the smooth implementation of the "Belt and Road" strategy, a large number of highly qualified international talents are needed. This undoubtedly puts forward new requirements for the international exchange work of universities along the route, especially those in the west. Therefore, universities and colleges in the west should fully recognize their responsibilities, not only to see the challenges of international exchange and cooperation, but also to see good development opportunities with confidence, actively seek effective measures to do well in university construction, and make due contributions to the smooth realization of the "Belt and Road" economic strategy.
\end{abstract}

\section{Keywords}

The Belt and Road Initiative, Universities and Colleges in the West, Challenges and Opportunities

\section{Introduction}

As a saying goes "Centennial development should be education-oriented", education plays a key role in improving the quality of the people and promoting the long-term development of the country. Under the background of the "Belt and Road", the role of education is becoming more and more prominent, and it can 
provide talents for countries to actively participate in the Belt and Road. Therefore, the "Belt and Road" strategy will build an education community and vigorously promote international cooperation in the field of education (Cui, 2019). Western colleges and universities all play an important role in the "Belt and Road" strategy and its influence. Therefore, western colleges and universities should keep pace with the times, seize the opportunity of international exchange and cooperation under the "Belt and Road" strategy, and do well in researches on international exchange and cooperation, meet challenges, seize opportunities, and actively become a promoter of the realization of the "Belt and Road" strategy.

\section{Challenges of International Exchange and Cooperation Facing the Facing Universities and Colleges under the Background of the Belt and Road Initiative}

\subsection{The Comparative Lack of High-Level Talents in Western Universities and Colleges}

Under the background of the "Belt and Road" initiative, international exchanges and cooperation cannot be separated from the support of high-level talents. However, affected by the uneven economic development, western colleges and universities are facing the challenge of lack of high-level talents. Firstly, there are a large number of countries along the "Belt and Road" route. Not only are there major differences in national languages, but there are also many official languages, and the demand for high-level talents is more diverse. Secondly, the economic development of countries along the route is uneven and the economic level is uneven (Yang, 2018). At the same time, some countries are not stable enough, the internal situation is volatile, and there are many insecure factors. Thirdly, the customs and cultural environment of the countries along the route vary greatly. Based on the above reasons, in order to achieve deep cooperation, more high-level talents with superb business skills and familiar with the political, economic and cultural background of each country are needed. However, the analysis found that both the number of universities and colleges in the west and the number of high-level talents are still relatively lacking and that the problems in Ningxia, Qinghai, and Tibet are even more serious. Although the "Belt and Road" University Strategic Alliance was established in October 2015, a total of 46 colleges and universities participated in it to cultivate high-quality talents with an international perspective. However, it still takes time to truly serve the "Belt and Road" initiative.

\subsection{Low Level of International Exchange and Cooperation in Western Universities and Colleges}

The overall level of international exchange and cooperation in western universities is relatively low. First, foreign exchange and cooperation are not coordinated. Western universities participating in international exchanges and cooperation are mainly those with strong strength, most of which are the former "211 Project" and "985 Project", and the proportion of other universities is relatively small. 
In addition, the cost becomes an important factor that hinders students from communicating abroad. Western colleges and universities have great differences in subsidizing students for overseas exchange, and most of them are self-financed students. Second, the structure of foreign students coming to China needs to be optimized. Western colleges and universities are less attractive to foreign students. Not only do high-level students account for a small proportion of foreign students coming to western colleges, but some international students lack the attention to the "Belt and Road" Initiative. In the course selection, students who choose majors related to the "Belt and Road" Initiative are comparatively rare (Qian, 2017).

\subsection{Western Universities and Colleges Have Limited Participation in International Exchange and Cooperation}

The limited participation in international exchanges and cooperation is one of the important challenges faced by western universities and colleges. On the one hand, although some strong universities actively participate in international exchanges and cooperation activities, and even set up related majors, focusing on training talents who meet the requirements of the "Belt and Road" initiative, yet due to the lack of teaching talents, most majors use Chinese as the language of instruction, thus increasing the difficulties of studying abroad and reducing the enthusiasm of studying abroad. In addition, although some colleges and universities have set up international education colleges, they only conduct foreign language teaching activities and have few substantive activities, which affects the full play of the role of international education colleges. On the other hand, in the international exchanges and cooperation, the professional level of the staff of the international colleges in western universities is comparatively low (Guo \& Wu, 2017). When choosing an exchange school, either only their own majors and disciplines are considered, or the exchange school is not practically selected, resulting in insufficient and stagnant international exchanges and cooperation.

\section{Opportunities Faced by Western Universities and Colleges in International Exchange and Cooperation in the Context of the Belt and Road Initiative}

Under the background of the "Belt and Road" Initiative, colleges and universities in the west should not only see the challenges, but also the opportunities they face, establish cultural self-confidence, dare to meet the challenges, firmly grasp the opportunities, steadily advance the construction of colleges and universities, and improve the quality and level of teaching while enhancing the competitiveness and international influence of universities and colleges in the west.

\subsection{Expand International Vision}

After the implementation of the "Belt and Road" strategy, the state has given great support, not only actively holding relevant meetings, but also promulgating a series of supporting policies. At the same time, major universities have responded 
to the "Belt and Road" initiative. In May 2015, Xi'an Jiaotong University led the establishment of the New Silk Road University Alliance. The establishment of the "Belt and Road" college strategic alliance in Dunhuang in October 2015 has greatly enhanced the enthusiasm of colleges and universities in the west to "go global" (Xu, 2017). As we all know, western colleges and universities are at a disadvantage in terms of geographical location, and lacked opportunities for international cooperation in previous developments. With the implementation of the "Belt and Road" strategy, this "interactive with international" pattern has been broken, and there are more western colleges to participate in the educational activities of countries along the route, integrate education and culture with different countries, help to expand the international horizons of universities and colleges in the west, and lay a solid foundation for better implementation of the "Belt and Road" strategy.

\subsection{Improve Level of the School}

The Belt and Road Initiative provides good opportunities for the flow of talents and ideas from countries along the route. "Flow" here includes two meanings: First, encourage excellent and powerful teachers to "go out", and combine the actual conditions of the countries along the route to teach students according to their aptitude and cultivate more "Belt and Road" builders. Second, bring in teachers from countries along the route who are interested in building the "Belt and Road" initiative. The combination of "going out" and "bringing in" has made the educational resources in the western region go international while providing teachers with a good opportunity to learn some advanced teaching theories of the country ( $\mathrm{Li} \& \mathrm{Ma}, 2017)$. At the same time, in the process of "bringing in", it will attract more excellent teachers from countries along the route to participate in the educational activities of western colleges and universities, inject fresh blood into these schools, improve their level of education and make up for the shortage of high-level talents in western colleges and universities. The further improvement of the school-running level paves the way for further strengthening the influence of western colleges and universities in the "Belt and Road" initiative.

\subsection{Innovate the Form of Running Schools Abroad}

Running schools abroad is an important manifestation of international exchanges and cooperation between universities and colleges, and an important measure to cultivate more talents who serve the "Belt and Road" initiative (Liu, 2018). The implementation of the "Belt and Road" strategy has made the educational cooperation between western colleges and countries along the route closer, that is, through in-depth exchanges and cooperation with the countries along the route, western colleges and universities can further deepen their understanding of the culture, politics and education of different countries to provide a basis for more scientific and reasonable overseas school programs and innovations in overseas school modes to promote the efficient flow of outstanding talents on the job 
(Liu, 2016). At the same time, on the basis of clarifying the deficiencies and advantages of education in the countries along the route, western colleges and universities combined their own majors, fully utilized the educational resources of the countries along the route, actively promoted the innovation of overseas school-running forms, paid attention to the output of high-quality teaching resources, and learned complementary advantages from others and further improved the level and quality of overseas schools while improving the quality and level of education in the countries along the route, As General Secretary Xi Jinping mentioned in his speech, "actively explore, carry out various forms of overseas cooperation in running schools, so that students can fully grow in exchanges."

\section{Measures for International Exchange and Cooperation in Western Universities and Colleges under the Background of the Belt and Road Initiative}

In order to actively respond to the challenges faced in international cooperation and exchanges under the background of the "Belt and Road", universities in the west should sum up past experience, actively seek effective measures for international exchanges and cooperation, and lay a solid foundation for the construction of an educational community.

\subsection{Study Relevant Policies and Get More Support and Care}

Under the background of the Belt and Road Initiative, international exchanges and cooperation between universities in the west and national policies are inseparable. Therefore, universities in the west should do a good job in studying the national policies of the "Belt and Road", grasp policy trends, actively respond to national calls, broaden their horizons, and strive to develop their own advantages. At the same time, by strengthening their own education to make up for the shortcomings. At the same time, in response to the state's support, universities in the west should actively declare their own conditions to make up for the shortcomings in international exchanges and cooperation. If the country leans toward western colleges and universities on scholarships, western colleges and universities should seize this opportunity to send more students to countries along the "Belt and Road" for exchange and cooperation. At the same time, local governments should fully recognize the opportunities brought by the "Belt and Road" to the development of local colleges and universities, implement the "Belt and Road" policy without compromise, combine the reality of western colleges and universities, and provide maximum help to solve the problems of western colleges and universities. The difficulties encountered in "going out" have become an important supporting force behind it.

\subsection{Give Full Play to Your Own Advantages and Find a Breakthrough in Educational Cooperation}

In order to further enhance their attractiveness, western colleges and universities should take effective measures to improve their own strength. They must do a 
good job in training talents and setting majors, find room for improvement, actively build brand majors, and increase their influence and popularity at home and abroad, training and attracting more high-level talents to make up for the shortage of high-level talents. At the same time, these colleges and universities should do a good research about students who study abroad and those who study in China, master the way students are keen to study abroad, exchange in-depth views with countries along the "Belt and Road", find effective breakthroughs in educational cooperation, innovate educational cooperation models, and continue to inspire students' enthusiasm for studying abroad. In addition, colleges and universities in the western region can appropriately increase the funds for studying abroad in light of local economic condition.

\subsection{Enhance the Awareness of International Cooperation and Improve the Comprehensive Quality of Relevant Personnel}

Under the background of the "Belt and Road" initiative, the international exchanges and cooperation between universities and colleges in the west are closely related to the understanding of the universities and the comprehensive quality of the relevant staff. In order to better meet the challenges, on the one hand, the colleges and universities in the west guide the staff to study the content of the relevant documents of the Belt and Road Initiative and knowledge about internationalization and increase awareness of international cooperation. At the same time, the "Belt and Road" is highly valued by the country, and this opportunity should be actively seized. On the other hand, western colleges and universities should do professional training for personnel involved in international exchanges, gain a deep understanding of the education development in countries along the route, correct attitudes, conduct in-depth demonstrations, and formulate reasonable and detailed plans about international exchanges and cooperation.

\subsection{The Managerial Mechanism of International Exchange and Cooperation of Local Colleges and Universities Should Be in Line with International Standards}

As a manager engaged in international exchange, it is necessary to strengthen the managerial system of international exchange and cooperation, continuously promote the managerial system of local colleges and universities, innovate the working methods of international exchange and cooperation, and provide a solid system to guarantee the implementation of international exchange and cooperation. It is also necessary to strengthen the publicity catering to teachers and students throughout the school, encourage all personnel of the school to participate in international exchange and cooperation, increase the funds for activities in international exchange and cooperation, and fully mobilize the enthusiasm of the teachers and researchers to achieve a comprehensive and interactive participation mechanism, thus conforming with the education and teaching of colleges and universities all over the world and to internationalize and modernize the management in international exchange and cooperation of local colleges and universities. 


\section{Acknowledgements}

Fund project: 2018 School-Based Research Project of Sichuan University of Arts and Sciences (Taking Sichuan University of Arts and Sciences as an Example for the Research on the Internationalization Development Strategy of Western Local Universities under the Background of One Belt and One Road), subject number: $2018 X B 001 Z$.

\section{Conflicts of Interest}

The author declares no conflicts of interest regarding the publication of this paper.

\section{References}

Cui, Y.Z. (2019). Opportunities and Challenges Faced by Ideological and Political Work in Tibetan Colleges and Universities under the Background of "the Belt and Road" Initiative. Chinese Journal of Multimedia and Network Teaching (Early Issue), 4, 207-208.

Guo, F., \& Wu, X. (2017). International Science and Technology Cooperation in Western Universities under the "Belt and Road" Strategy. Science and Technology of Chinese Universities, 2, 81-82.

Li, K., \& Ma, J. (2017). Views on the Exchanges and Cooperation between Western Universities and Colleges under the Background of the "Belt and Road" Initiative. Journal of Yanbian Education College, 4, 68-71.

Liu, G. (2016). Analysis of the Development Opportunities for Western colleges and Universities under the Background of the "Belt and Road" Initiative. Journal of Higher Education, 10, 21-22.

Liu, Q. (2018). Challenges and Countermeasures for Foreign Exchanges and Cooperation of western Colleges and Universities under the Background of the "Belt and Road" Initiative. Chongqing Higher Education Research, 1, 12-19.

Qian, C. (2017). Challenges and Countermeasures of Ideological and Political Education in Colleges and Universities under the Background of "the Belt and Road" Initiative. Journal of Xinyang Agriculture and Forestry College, 4, 156-157+160.

$\mathrm{Xu}, \mathrm{L}$. (2017). The Opportunities and Challenges of the "Belt and Road"Initiative That the Poor Minority Students in Western Colleges and Universities Face. Education and Teaching Forum, 48, 48-49.

Yang, J. (2018). The Opportunities and Challenges of "the Belt and the Road" to College Education in China. Education Teaching Forum, 1, 213-214. 